https://doi.org/10.52288/bp.27089851.2020.12.03

\title{
The Theoretical Possibility of the Mundellian-Trilemma in Practice
}

\author{
Helen Zhang ${ }^{1 *} \quad$ Lu- Yao Wang ${ }^{2}$
}

\begin{abstract}
Mundellian-Trilemma depicts that the impossibility of three policy goals, monetary policy independence, open capital market and fixed exchange rate. The depiction of Mundellian-Trilemma appears true under an assumption of zero arbitrage costs across international markets. In practice, however, the transaction costs can be enormous to hinder the capital cross international markets. Hence, by relaxing the assumption of zero arbitrage costs, this paper demonstrates a theoretical possibility of the trilemma in practice.
\end{abstract}

Keywords: Mundellian Trilemma, Monetary Policy, Open Capital Market, Exchange Rate System

\section{Introduction of the Mundellian-Trilemma}

The trilemma is a well-known theory in the field of contemporary international economics. The theory of trilemma was first proposed by the famous British economist Mead (1953). In his book "The Balance of Payments", Mead pointed out that in the current open economy, to achieve a true internal and external balance, to fully rely on the reasonable collocation and application of policies and choose a fixed exchange rate policy, the government cannot use the exchange rate policy. Moreover, if the government only relies on the main expenditure policy to change the fiscal policy and fixed monetary policy, it may lead to the goal execution of internal equilibrium and external equilibrium conflicts and cannot be achieved smoothly. Mead believes that if the government wants to implement a fixed exchange rate system, it must strictly implement capital controls. The conflict between the free flow of capital and the fixed exchange rate system ("dual conflict") has laid an important foundation for the proposal and development of the "Trilemma" theory.

The Mundellian-trilemma states that it is not feasible to have a fixed exchange rate, full capital mobility and monetary policy independence at the same time. Only two of the three policy goals may coexist. After the Asian financial crisis in March 2008, Krugman (1999) made a series of in-depth discussions on several important issues of this basic principle in his book "The Return of Depression Economics", and claimed that it is impossible for a country to achieve monetary policy independence, exchange rate stability, and free flow of capital at the same time. It can only choose two of them at the same time and abandon the others.

The Mundellian-trilemma can be more intuitively represented by Figure 1. In the triangle, when the government chooses one of its sides, it can only get the two vertices of this side, that is, it can only achieve two of the three policy goals. For example, when the government chooses the right side, it means that the government has chosen independent monetary policy and the free flow of capital, and has given up fixed exchange rate.

\footnotetext{
${ }^{1}$ Lecturer of School of International Business, Xiamen University Tan Kah Kee College, hzhang@xujc.com * corresponding author

2 School of International Business, Xiamen University Tan Kah Kee College
} 


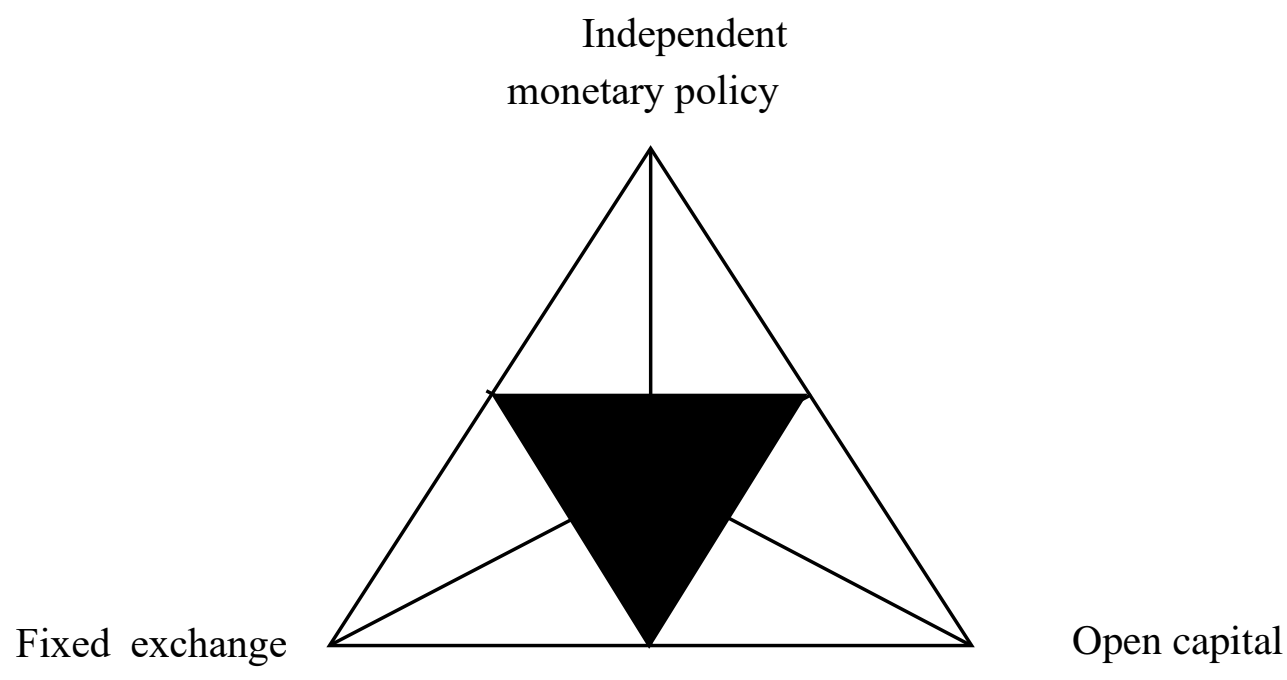

Figure 1. Mundellin-Trilemma

In 2000, based on the "Trilemma", Yi, an economist and the current governor of the People's Bank of China, proposed a triangle model which can be expanded and supplemented with a concise formula:

$$
\mathrm{X}+\mathrm{Y}+\mathrm{M}=2
$$

where $\mathrm{X}$ represents the exchange rate, $\mathrm{Y}$ represents the monetary policy, M represents the flow of capital.

These three variables $\mathrm{X}, \mathrm{Y}$, and $\mathrm{M}$ range from 0 to $1, \mathrm{X}=0$ means a completely free floating exchange rate system, $\mathrm{X}=1$ means a completely fixed exchange rate system; $\mathrm{Y}=$ 0 means a currency union, $\mathrm{Y}=1$ represents the complete independence of the country's monetary policy; $\mathrm{M}=0$ represents complete control of capital, $\mathrm{M}=1$ represents the complete free flow of capital. The remaining intermediate values represent the intermediate state, that is, the middle of the "Triple Paradox" diagram, the non-corner solution of the zone.

According to Yi's formula, we can get the policy combination of three corner solution (Xiong et al., 2009):

a) Combine the policy combination of the corner point $(0,1,1)$, that is, the government chooses to maintain the independence of monetary policy and the free flow of capital but abandon the fixed exchange rate system. In this case, a free-floating exchange rate system is implemented, allowing free capital output and input, and the government can implement a monetary policy that modulates market interest rates in a timely manner based on the domestic macroeconomic situation. In this way, the government can better protect the domestic economy from the impact of a large amount of circulating capital and achieve domestic economic goals at a certain level, but this also means that the country needs to tolerate the risks caused by floating exchange rates.

b) The combination of monetary policy at the corner point, $(1,0,1)$, represents that the government directly implements free flow of capital and a fixed currency exchange rate system, abandoning the independence of domestic monetary policy. This combination could sharply cutoff the effectiveness of domestic monetary policy. The domestic currency interest rate will not only be determined by the supply and currency demand in the domestic market 
but also be consistent with the interest rate in international markets. Because of the free flow of capital, any slight difference in interest rates will attract arbitraging across the domestic and foreign capital markets.

c) The corner point $(1,1,0)$ indicates that the government intends to implement a stable exchange rate system and ensure the independence of its monetary policy while implementing strict capital market controls. In this case, the government may make timely policy adjustments to the macroeconomic situation by controlling the capital flows across domestic and international capital markets.

\section{Mundellian-Trilemma in Practice}

The principle of Trilemma is highly abstract and only considers extreme cases, namely complete monetary policy independence, complete fixed exchange rate, and complete free flow of capital, without discussing intermediate situations. In practice, however, there is hardly any direct evidence for the "mutual incompatibility of fixed exchange rates, monetary independence, and perfect capital mobility" (Rose, 1996). On the contrary, some empirical facts are inconsistent with the depiction of the trilemma.

There may be two main reasons for the invalid description of the trilemma. One is about the assumption of a fixed exchange rate (Bordo \& MacDonald, 2003). In fact, the nominal exchange rate is rarely completely fixed. For example, under the Bretton Woods system, the nominal exchange rate is allowed to fluctuate within a range of $\pm 1 \%$, while under the European monetary system, it is allowed to fluctuate within a range of $\pm 2.25 \%$. In addition, during the classical gold standard period, there were golden points to tolerate exchange rate fluctuations. Violation of the fixed exchange rate assumption may leave room for different interest rates.

Another reason for the ineffectiveness of the Trilemma may be that UIP conditions are used as a proxy for the open capital market. UIP has hardly conducted empirical studies, mainly because UIP assumes that arbitrage across international capital markets is cost-free, which is unrealistic in practice. For example, Baldwin (1990) claimed that even a small transaction cost may bring considerable annualized interest rate differences between countries. Market risks, market deficiencies, regulations, institutional practices, transaction costs and/or asset portfolio adjustment costs may also increase arbitrage costs and cause the failure of UIP conditions (Svensson, 1992). Even taxation can have a significant impact on international capital flows (Escudé, 2013; 2014) and may severely hinder or stimulate international investment. Sinn (1988) pointed out that between 1983 and 1985, nonresidential fixed income (bond) investment in the United States rose sharply due to the 1981 tax reform. In addition, Madura (2012) graphically shows that there is a non-profit arbitrage interval near interest rate parity due to transaction costs, political risks and differential tax laws. Therefore, unlike the problem of a fixed exchange rate system, the failed UIP conditions may provide room for interest rate differentials and simultaneously realize the three policy dimensions of the Trinity in practice.

In short, the inevitable cost of arbitrage across international capital markets may make the impossible open policy trilemma possible in practice.

\section{An Arbitrage-cost-band Model}

The idea of arbitrage costs is not novel. A number of researchers have considered it while investigating the covered interest rate parity (CIP), the uncovered interest rate parity (UIP), and the purchasing power parity in international financial markets. Miller (2014) even mentions that the hypothesis of a "zone of speculative inactivity" based on transaction costs could be a key to the UIP puzzle. Moreover, Grenville (2011) finds that the trilemma 
does not hold in Indonesia and Thailand due to the presence of substantial risk from their less-substitutable currencies. However, few researchers explicitly connect arbitrage costs and the failure of the UIP with a general validity of the trilemma in practice. This section will demonstrate how incorporated arbitrage costs in the UIP condition could possibly invalid the trilemma postulate.

Let us assume two countries with two national currencies, open capital markets, floating exchange rate regimes, and no default risk. Investors will go long on country $i$ 's currency and go short on country $j$ 's currency if the return on country $i$ 's currency is greater than a round-trip arbitrage costs plus the interest on country $j$ 's currency:

$$
\left(1+R_{t}^{i}\right)>\frac{F_{t}^{i j}}{s_{t}^{i j}} *\left(1+R_{t}^{j}\right) *\left(1+C_{t}^{i j}(.)\right)
$$

where $F_{t}^{i j}$ denotes the forward exchange rate in terms of country $i$ 's currency per unit of country $j$ 's currency at time $t ; C_{t}^{i j}($.$) is a function of round-trip arbitrage costs estimated$ at time $t$ while going long on country $i$ 's currency and going short on country $j$ 's currency, and closing all positions at maturity.

No arbitrage will occur from country $i$ to country $j$ if the return on country $i$ 's currency is less than round-trip arbitrage costs plus the interest on country $j$ 's currency but not low enough to a level which could attract arbitrageurs to go short on country $i$ 's currency and go long on country $j$ 's currency:

$$
\left(1+R_{t}^{i}\right) \leq \frac{F_{t}^{i j}}{s_{t}^{i j}} *\left(1+R_{t}^{j}\right) *\left(1+C_{t}^{i j}(.)\right)
$$

Similarly, investors will go long on country $j$ 's currency and go short on country $i$ 's currency if the return on country $j$ 's currency is greater than round-trip arbitrage costs plus the interest on country $i$ 's currency:

$$
\left(1+R_{t}^{i}\right) *\left(1+C_{t}^{j i}(.)\right)<\frac{F_{t}^{i j}}{s_{t}^{i j}} *\left(1+R_{t}^{j}\right)
$$

where $C_{t}^{j i}($.$) is a function of round-trip arbitrage costs estimated at time t$ while going long on country $j$ 's currency and going short on country $i$ 's currency, and closing all positions at maturity.

Accordingly, no arbitrage will happen from country $j$ to country $i$ if the return on country $j$ 's currency is less than round-trip arbitrage costs plus the interest on country $i$ 's currency but not low enough to make a profit by going long on country $i$ 's currency and going short on country $j$ 's currency:

$$
\left(1+R_{t}^{i}\right) *\left(1+C_{t}^{j i}(.)\right) \geq \frac{F_{t}^{i j}}{s_{t}^{i j}} *\left(1+R_{t}^{j}\right)
$$

From inequalities (1) - (4), we can deduce a non-arbitrage band:

$$
\frac{F_{t}^{i j}}{s_{t}^{i j}} * \frac{\left(1+R_{t}^{j}\right)}{\left(1+C_{t}^{j i}(.)\right)} \leq\left(1+R_{t}^{i}\right) \leq \frac{F_{t}^{i j}}{s_{t}^{i j}} *\left(1+R_{t}^{j}\right)\left(1+C_{t}^{i j}(.)\right)
$$


Rearranging inequality (5):

$$
\frac{F_{t}^{i j}}{s_{t}^{i j}} * \frac{\left(1+R_{t}^{j}\right)}{\left(1+C_{t}^{j i}(.)\right)}-1 \leq R_{t}^{i} \leq \frac{F_{t}^{i j}}{s_{t}^{i j}} *\left(1+R_{t}^{j}\right)\left(1+C_{t}^{i j}(.)\right)-1
$$

As we can see from inequality (5), if we neglect arbitrage costs by assuming $C_{t}^{i j}()=$. $C_{t}^{j i}()=$.0 , we will have the CIP condition:

$$
\left(1+R_{t}^{i}\right)=\frac{F_{t}^{i j}}{S_{t}^{i j}} *\left(1+R_{t}^{j}\right)
$$

The CIP is a condition to rule out risk-free arbitrage opportunities. However, in practice, neither the terms of a forward contract on exchange rates could fit all needs of arbitrageurs, such as contract sizes and time periods, nor could all exchange rates have forward contracts or other financial derivatives in markets to cover the exchange rate risk borne in on arbitraging. Therefore, a substantial number of arbitrageurs replace the forward exchange rate $F_{t}^{i j}$ in the CIP with an expected spot nominal exchange rate $E_{t}^{i j}$ at time $t$ for the end of their arbitrage period to assess trading strategies. This kind of arbitrage is related to the UIP condition because the exchange rate risk is uncovered by counterpart derivatives.

Hence, we could substitute the forward exchange rate $F_{t}^{i j}$ with a one-period-ahead expectation of the nominal exchange rate $E_{t}^{i j}$ in inequality (5):

$$
\begin{aligned}
& \frac{E_{t}^{i j}}{s_{t}^{i j}} * \frac{\left(1+R_{t}^{j}\right)}{\left(1+C_{t}^{j i}(.)\right)} \leq\left(1+R_{t}^{i}\right) \leq \frac{E_{t}^{i j}}{s_{t}^{i j}} *\left(1+R_{t}^{j}\right) *\left(1+C_{t}^{i j}(.)\right) \\
& \frac{E_{t}^{i j}}{s_{t}^{i j}} * \frac{\left(1+R_{t}^{j}\right)}{\left(1+C_{t}^{j i}(.)\right)}-1 \leq R_{t}^{i} \leq \frac{E_{t}^{i j}}{s_{t}^{i j}} *\left(1+R_{t}^{j}\right) *\left(1+C_{t}^{i j}(.)\right)-1
\end{aligned}
$$

We will arrive at the UIP if we assume arbitrage costs $C_{t}^{i j}()=.C_{t}^{j i}()=$.0 :

$$
\left(1+R_{t}^{i}\right)=\frac{E_{t}^{i j}}{s_{t}^{i j}} *\left(1+R_{t}^{j}\right)
$$

The UIP is universally rejected in empirical research, especially in the short run. From inequality (7), we can conclude that two potential sources could contribute to the failure of the UIP. One is that the variables included in the function of arbitrage costs, such as risk premiums, are missing in Fama regressions. Another source is the expectation errors of nominal exchange rates from $E_{t}^{i j}$.

Empirically, Miller (2014) summarizes that risk premiums and exchange rate expectation errors are two main candidates towards solving the UIP puzzle (also known as "the forward discount/premium bias"). Engel (1996) concludes that only the risk premium is not sufficient enough to explain negative estimates of the $\beta$ coefficient in Fama regressions. Froot and Frankel (1989) claim that the variance of risk premiums is relatively small compared with the variance of expected currency depreciation; moreover, they surprisingly find that the level of risk premiums tends to be constant, and this finding is contrary to conventional thought (Froot \& Frankel, 1989). Since Froot and Frankel do not 
separate trading costs from risk premiums they measured, the "constant risk premium" in their findings could be considered as arbitrage costs in inequality (7). Therefore, if the proportion of actual risk premiums is relatively small in the total arbitrage cost function in inequality (7), the value of the arbitrage costs could be comparatively stable since other components, such as tax rates and bid-ask spreads, are almost constant on average in a short run.

Furthermore, "extreme support" from large differentials of interest rates for the UIP implies that the large (outlier) values of interest rate differences attract more carry-trade than the small ones (Craighead et al., 2010). Craighead et al. (2010) also suggest that a zone of speculative inactivity exists. The exchange rate band caused by arbitrage costs in this paper is partially consistent with the concept of an inactive speculative zone except the band formed by arbitrageurs is usually wider than the one for speculators since arbitrageurs are assumed to take no risks.

Moreover, despite the exchange rate regime officially claimed by a country, neither a completely floating exchange rate regime nor a strictly fixed exchange rate regime could be easily found in reality. If we draw a straight line between the bipolar exchange rate regimes, we could possibly range all countries between a totally fixed exchange rate regime and a completely free floating regime according to the flexibility of nominal exchange rates managed by their central banks (Frankel, 2012). Therefore, an exchange rate target zone, $(1 \pm \theta) * S_{t}^{i j}$, could be adapted into inequality (7) as follows:

$$
(1-\theta)=\frac{(1-\theta) s_{t}^{i j}}{s_{t}^{i j}} \leq \frac{E_{t}^{i j}}{s_{t}^{i j}} \leq \frac{(1+\theta) s_{t}^{i j}}{s_{t}^{i j}}=(1+\theta)
$$

where, $\theta$ is the targeted percentage changes regarded to the nominal exchange rate. Then the band in inequality (7) will become:

$$
\begin{gathered}
(1-\theta) * \frac{\left(1+R_{t}^{j}\right)}{\left(1+C_{t}^{j i}(.)\right)} \leq\left(1+R_{t}^{i}\right) \leq(1+\theta) *\left(1+R_{t}^{j}\right) *\left(1+C_{t}^{i j}(.)\right) ; \theta \in(0,+\infty) \\
(1-\theta) * \frac{\left(1+R_{t}^{j}\right)}{\left(1+C_{t}^{j i}(.)\right)}-1 \leq R_{t}^{i} \leq(1+\theta) *\left(1+R_{t}^{j}\right) *\left(1+C_{t}^{i j}(.)\right)-1 ; \theta \in(0,+\infty)
\end{gathered}
$$

As shown in inequality (9), $R_{t}^{i}$ could differ from $R_{t}^{j}$ under a nominal exchange rate target zone. It can be set within a range of $\left[(1-\theta) * \frac{\left(1+R_{t}^{j}\right)}{\left(1+C_{t}^{j i}(.)\right)}-1,(1+\theta) *\left(1+R_{t}^{j}\right) *\right.$ $\left.\left(1+C_{t}^{i j}().\right)-1\right]$ as indicated in inequality (9'). The differential of interest rates across countries is positively related to the width of a target zone and the magnitude of arbitrage costs. Moreover, the higher the interest rate of a paired-country is, the wider the interest rate gap could be between the country-pair. Svensson (1994) shows that the standard deviation of Sweden's interest rates can be lessened by about a half with a \pm 2 percent target zone. Following Svensson's hypothesis, Bordo \& MacDonald (2003) investigate the gauge of monetary independence under the gold exchange standard during 1880-1914 and inter-war 
periods. Furthermore, they evidence that the authorities with a credible target zone could manipulate short-term interest rates to absorb shocks and influence output, gold reserves, prices and other aggregate variables (Bordo \& MacDonald, 2003).

More interestingly, in inequality (9), $\theta=+\infty$ could represent a completely floating exchange rate regime. The interest rate differentials across countries could be infinitely large and central banks could enjoy fully monetary independence as conventional wisdom suggested. Moreover, $\theta=0$ means that the nominal exchange rate is strictly fixed, and inequality (9) will be as follows:

$$
\begin{aligned}
& \frac{\left(1+R_{t}^{j}\right)}{\left(1+C_{t}^{j i}(.)\right)} \leq\left(1+R_{t}^{i}\right) \leq\left(1+R_{t}^{j}\right) *\left(1+C_{t}^{i j}(.)\right) \\
& \frac{\left(1+R_{t}^{j}\right)}{\left(1+C_{t}^{j i}(.)\right)}-1 \leq R_{t}^{i} \leq\left(1+R_{t}^{j}\right) *\left(1+C_{t}^{i j}(.)\right)-1
\end{aligned}
$$

Inequality (10) and (10') show that the interest rates between two countries are not necessarily identical even under a strictly fixed exchange rate regime, though the degree of monetary independence faced by policy makers will depend on the size of the band, $\left[\frac{\left(1+R_{t}^{j}\right)}{\left(1+C_{t}^{j i}(.)\right)}-1,\left(1+R_{t}^{j}\right) *\left(1+C_{t}^{i j}().\right)-1\right]$, introduced by arbitrage costs.

Therefore, the three desirable policy goals, independent monetary policy, an open capital market and a fixed exchange rate regime, could be achieved simultaneously within an arbitrage cost band. Moreover, since capital gain tax or withholding tax are also part of arbitrage costs, fiscal policies on relative tax rates could be formulated to widen the possible interest rate wedge across countries; and hence it will give more leeway to monetary policy on the manipulation of the nominal interest rate.

\section{Conclusion}

This paper theoretically illustrates that there are not only trade-offs among the three policy dimensions of the trilemma, but also a corner solution of the trilemma might exist within the arbitrage cost band. The demonstration in section 3 presents a scenario that a country may have a strictly fixed exchange rate, an open capital market, and monetary independence within an arbitrage cost band. The gauge of monetary independence that a central bank may have depends on the width of the arbitrage cost band. The wider the arbitrage cost band, the more monetary independence. Moreover, it is possible for policymakers to amend regulations/laws on tax rates, margin requirements, and mark-ups to adjust the width of the arbitrage cost band, and hence, affect the gauge of monetary independence.

\section{References}

1. Angrick, S. (2015). Global liquidity and monetary policy autonomy. IMK at the Hans Boeckler Foundation, Macroeconomic Policy Institute.

2. Baldwin, R. E. (1990). Re-interpreting the failure of foreign exchange market efficiency tests: Small transaction costs, big hysteresis bands. No. w3319, National Bureau of Economic Research.

3. Bordo, M. D., \& MacDonald, R. (2003). The inter-war gold exchange standard: Credibility and monetary independence. Journal of International Money and Finance, 22(1), 1-32. 
4. Craighead, W. D., Davis, G. K., \& Miller, N. C. (2010). Interest differentials and extreme support for uncovered interest rate parity. International Review of Economics \& Finance, 19(4), 723-732.

5. Engel, C. (1996). The forward discount anomaly and the risk premium: A survey of recent evidence. Journal of Empirical Finance, 3(2), 123-192.

6. Escudé, G. J. (2013). A DSGE model for a SOE with systematic interest and foreign exchange policies in which policymakers exploit the risk premium for stabilization purposes. Economics: The Open-Access, Open-Assessment E-Journal, 7(30), 1-110.

7. Escudé, G. J. (2014). The possible trinity: Optimal interest rate, exchange rate, and taxes on capital flows in a DSGE model for a small open economy. Economics: The Open-Access, Open-Assessment E-Journal, 8(25), 1-58.

8. Frankel, J. A. (2012). Choosing an exchange rate regime. In Handbook of Exchange Rates, James, J., Marsh, I. W., \& Sarno, L. (Eds.), 765-782

9. Froot, K. A., \& Frankel, J. A. (1989). Forward discount bias: Is it an exchange risk premium? The Quarterly Journal of Economics, 104, 139-161.

10. Gang, Y. (2000). The choice of foreign exchange rate regime. Journal of Financial Research, 9, 46-52.

11. Grenville, S. (2011). The impossible trinity and capital flows in East Asia. ADBI Working Paper, 319.

12. Kawai, M., \& Liu, L. G. (2015). The trilemma of the Chinese economy is facing. New Finance, 6, 13-19.

13. Krugman, P. (1999). The return of depression economics. Beijing: Renmin University of China Press.

14. Madura, J. (2012). International financial management (12th Edition) Cengage Learning.

15. Mao, D. J. (2006). Look at China's exchange rate system reform from the trinity paradox. Gansu Agriculture, 9, 73-74.

16. Meade, J. (Li, Z. translated) (2001). Theory of international economic policy, Volume One: Balance of Payments. Beijing: Capital University of Economics and Business Press.

17. Miller, N. C. (2014). Exchange rate economics: The uncovered interest parity puzzle and other anomalies. VA: Edward Elgar Publishing.

18. Rose, A. K. (1996). Explaining exchange rate volatility: An empirical analysis of "the holy trinity" of monetary independence, fixed exchange rates, and capital mobility. Journal of International Money and Finance, 15(6), 925-945.

19. Sinn, H. (1988). US tax reform 1981 and 1986: Impact on international capital markets and capital flows. National Tax Journal, 41(3), 327-340.

20. Svensson, L. E. (1992). The foreign exchange risk premium in a target zone with devaluation risk. Journal of International Economics, 33(1), 21-40.

21. Wu, K., Wang, H. L., \& Que, Y. H. (2012). An empirical analysis of the independence and effectiveness of China's monetary policy. Finance, 2(3), 143-150.

22. Xiong, J., Wang, G. M., \& Zeng, G. (2009). Thoughts on the reform of China's exchange rate system based on the "Triple Paradox". Times Finance, 5, 36-37.

23. Xiang, C. F. (2012). Thinking about China's exchange rate system triggered by the ternary paradox. China Economic and Trade Guide, 21, 68-69.

24. Yang, Y. Q. (2016). Talking about China's capital flow and exchange rate system under the ternary paradox. Quotient, 2, 159+131. 